\title{
Vocabulary Acquisition through Self-Regulated Learning on Speaking and Writing Development
}

Budi Waluyo

Walailak University, Thailand

Email: budi.business.waluyo@gmail.com

How to cite this paper: Waluyo, B. (2018). Vocabulary Acquisition through SelfRegulated Learning on Speaking and Writing Development. International Journal of Language Teaching and Education, 2(3), 286-302.

https://doi.org/10.22437/ijolte.v2i3.5747

Accepted: October 18, 2018

Published: November 30, 2018

Copyright (c) International Journal of Language Teaching and Education.

This work is licensed under the Creative

Commons Attribution International License (CC BY 4.0).

http://creativecommons.org/licenses/by/4 $.0 /$

(c) (i)
Abstract

Despite the crucial role of vocabulary in foreign language acquisition, little is known about its influence on speaking and writing development from self-regulated learning concept. Thus, by employing a path analysis, this study examines the influence of vocabulary acquisition through self-regulated learning on beginner $(N=215)$ and intermediate $(N=195)$ students' speaking and writing development at Walailak University, Thailand. The findings suggest significant paths from vocabulary acquisition to students' speaking and writing development, but noting the influence of proficiency level. These findings contribute to the development of research in vocabulary acquisition and self-regulated learning with regards to speaking and writing development.

\section{Subject Areas}

Vocabulary Acquisition and Self-Regulated Learning

\section{Keywords}

Self-Regulated Learning, Speaking, Vocabulary Acquisition, Writing

\section{Introduction}

Vocabulary acquisition is undeniably vital for the development of learner's ability in performing the four language skills, encompassing reading, listening, writing, and speaking (Milton, 2013) and the contribution of vocabulary knowledge to learner's language proficiency has been found significant (Karakoç \& Köse, 2017). However, the result of a review of current studies on vocabulary acquisition only shows marginal vocabulary growth across vocabulary teaching and learning in various EFL situations, implying the existence of inefficient vocabulary learning (Chanturia \& Webb, 2016). Thus, the present study intends to offer some insights by exploring vocabulary acquisition through self-regulated learning and the effects on learner's improvement in speaking and writing skills. The vocabulary acquisition in this study involves explicit instruction in vocabulary learning that has been found effective in 
improving student's performance in vocabulary tests (Mizumoto \& Takeuchi, 2009) and recommended to be applied in foreign language classroom (De la Fuente, 2006; Sökmen, 1997).

There has been a growing body of literature around self-regulated learning due to its importance in supporting student's knowledge development both in formal schooling and in the periods where students must continue upgrading their capacity on their own (Boekaerts, 1997). Nonetheless, there is still a limited number of research exploring vocabulary acquisition through self-regulated learning. Meanwhile, given current technological developments, vocabulary learning taking place outside classrooms and in unsupervised environments can be inevitable and crucial for the success of student's vocabulary acquisition (Bjork, Dunlosky, \& Kornell, 2013). To put it simply, there are a lot of words that students must learn to be able to function the target language; a review of current studies on vocabulary learning discloses that, at least, learners need to have 8000-9000-word families for reading and about 5000-7000 families for oral discourse (Schmitt, 2008). Yet, teachers simply cannot teach all the words in classrooms due to time-constraints and other tolerable circumstances related to their teaching job. Therefore, embracing self-regulated learning in vocabulary acquisition is unavoidable for students to be proficient in the target language, and the findings of this study will examine the path to the development of speaking and writing skills.

\section{Literature Review}

\subsection{Vocabulary Acquisition through Self-Regulated Learning}

Self-regulated learning is viewed as a complex interactive process, involving not only cognition, but also motivation, in which learners take responsibility for their own learning process in a proactive way to achieve desired learning outcomes (Boekaerts, 1997; Zimmerman, 1990 \& 2002). In other words, learners self-initiate and self-manage learning that often goes beyond regular classroom schedules and takes advantage of available learning resources (Bjork, Dunlosky, \& Kornell, 2013). Early studies found the positive relationship between self-regulated learning and academic achievement (Lindner \& Harris, 1992; Zimmerman, 2008) and such relationship stays consistent as confirmed by recent studies (e.g. Dörrenbächer \& Perels, 2016; Duckworth, Akerman, MacGregor, Salter, \& Vorhaus, 2009). In foreign language learning, most of the studies about self-regulated learning happen around motivation and language learning strategies (e.g. Choi, Zhang, Lin, \& Zhang, 2018; Dörnyei, 1990; Tseng, Dörnyei, \& Schmitt, 2006; Zhang, Lin, Zhang, \& Choi, 2017).

In the field of vocabulary acquisition, one of the focused explorations is enhancing self-efficacy through self-regulated learning process, which 
potentially leads to the development of learner's vocabulary acquisition. Albeit self-regulated learning is more student-centered learning, some of the studies were surprisingly conducted in Asian countries that are widely known for the heavy teacher-centered learning approach. Mizumoto (2013a), for instance, integrated self-regulated learning approach into EFL learners' vocabulary learning at a university in Japan. Using experimental research design, a steady growth in self-efficacy and vocabulary knowledge was observed among students in the treatment groups. In another study, Mizumoto (2013b) examined self-regulated learning process on self-efficacy of EFL students from two universities in Japan, and supporting evidence was found that the process of self-regulated learning potentially boosts self-efficacy and increase vocabulary knowledge. Positive relationships between self-efficacy and selfregulation in vocabulary acquisition were also indicated among Chinese EFL learners (Ping, Baranovich, Manueli, \& Siraj, 2015) and Iranian EFL learners (Hamedani, 2013).

Vocabulary learning is a long-term task that requires students to maintain their motivation and adjust their learning strategies over time; thus, a proactive way of learning where students take control of their vocabulary learning is highly essential (Tseng \& Schmitt, 2008). The findings of the latest study from Choi, Zhang, Lin, and Zhang (2018) in Korea confirm that motivations were positively related to vocabulary learning strategies and vocabulary knowledge. Students who possessed stronger depth of vocabulary knowledge applied certain strategies more frequently than those with weaker depth of vocabulary knowledge (Nassaji, 2006). Self-regulated learning bridges between motivation and learning strategies in vocabulary learning (Mizumoto \& Takeuchi, 2011). Nevertheless, to build up self-regulation in vocabulary acquisition, students need practical self-regulatory process; providing a set of instructions or strategies would not help much (Tseng, Dörnyei, \& Schmitt, 2006).

However, the influence of motivational factors and self-regulatory strategies was not significantly different across learner groups (Kormos \& Csizer, 2014). Although good and poor language learners employed many effective strategies for vocabulary learning (Zhang, 2011), the differences were also noticeable in the aspects of metacognitive monitoring, self-efficacy, learning optimisim, and self-regulated language learning behavior (DiFrancesca, Nietfeld, \& Cao, 2016; Khodarahmi \& Zarrinabadi, 2016). Besides, motivation could only affect student's proficiency through learning strategies (Fukuda, 2018).

\subsection{Vocabulary Acquisition and Speaking Development}

It is unquestionable that, to be a proficient foreign language speaker, one needs to acquire wider and deeper vocabulary knowledge, which, in the process, 
improves clarity and fluency of spoken and written language (von Sydow, 2015). Vocabulary acquisition is a vital element to successfully developing communication and literacy skills (Belisle, 1997). Within all language skills and knowledge (listening, reading, speaking, and writing), vocabulary knowledge serves as an internal link, in which the development appears to be in parallel with the improvement of every other aspect of language (Jordan, 1997; Milton, 2013). On speaking development, for instance, Iwashita (2005) investigated lexical competence of learners preparing for tertiary study in English-speaking countries. The results of the study confirm that learners with higher level of language proficiency produced more academic vocabulary than those of lower proficiency. The parallel development of learner's vocabulary acquisition with other skills, such as listening, reading, and writing, has also been identified by recent empirical studies (e.g. Farvardin \& Teng, 2016; Harkio \& Pietilä, 2016).

Koizumi (2005) studied the relationship between vocabulary and speaking ability of Japanese learners of English at beginner level. A speaking test designed to assess school-based English proficiency and productive vocabulary knowledge test (VKT) were utilized to collect the data, which were, then, analyzed by using path analysis. The findings of the study revealed the presence of substantial effects of vocabulary knowledge and learners' speaking ability, which, further, suggests the enhancement of speaking ability by increasing vocabulary knowledge. Nevertheless, the attention should also be paid to the ability of putting vocabulary knowledge into use. In another study involving novice to intermediate levels, Koizumi \& In'nami, (2013) found that L2 speaking proficiency was predicted by L2 vocabulary knowledge, size, depth, and speed. The finding supports the view that more proficient learners exhibit higher vocabulary knowledge, thereby displaying higher speaking proficiency.

From teachers and students' perspectives, lack of vocabulary is often the reason in students' inability to speaking English (Khan, Radzuan, Shahbaz, Ibrahim, \& Mustafa, 2018; Seffar, 2011). This implicitly confirms the positive relationship between vocabulary acquisition and speaking development. Given the encouraging results of previous studies, the present study, hence, tries to examine if a positive relationship also exists between vocabulary acquisition through self-regulated learning and student's improvement in speaking skill.

\subsection{Vocabulary Acquisition and Writing Skill}

Like speaking, writing is also a productive skill in which the quality can depend on vocabulary knowledge level. Learners who have acquired more vocabulary would produce a better quality of written texts than those who have acquired less. Vocabulary knowledge simply allows learners to have a range of options in language production; in other words, the wider and deeper one's vocabulary knowledge, the further range of options one will have. A recent 
study from Viera (2017), for instance, explored the influence of vocabulary knowledge on written production. The results of the study confirm that a group of learners who received a pedagogic intervention with vocabulary activities performed better in written production that those who did not receive such intervention. The study, further, suggests the emphasis on advancing the vocabulary knowledge of the target language in use. Without having appropriate and sufficient vocabulary knowledge, learners would not be able to understand others or express their intentions.

The idea that inadequate knowledge of vocabulary in the target language may lead to inferior writing quality is supported by previous studies. For example, Shi and Qian (2012) examined the dimensions of vocabulary knowledge and the effects on EFL learners' writing quality. Their examination revealed that writing quality was strongly correlated with active vocabulary knowledge. The differences on learners' writing ability were found to be in parallel with learners' ability in vocabulary usage (Zhai, 2016), but differed by genre (Olinghouse \& Wilson, 2013). Meanwhile, leaners' use of academic words is more likely to be different by reading proficiency levels (Kim \& Ryoo, 2009). Nonetheless, Dobbs and Kearns (2016), who investigated the use of new vocabulary in writing, found that learners studying vocabulary for exams were more probable to attempt to use newly taught vocabulary in their writings than those learning English. Therefore, at this point, explicit instruction in vocabulary learning is necessary as it can help teach learners about how to use their store of recognition vocabulary as well as new vocabulary in a production task, such as writing (Lee, 2003).

\section{Methodology}

The This study employed a quantitative research design encompassing descriptive and inferential statistics. Instruments and materials for vocabulary, speaking, and writing were prepared for data collection. Students' scores in these skills were used as the primary data for the examination of the research question. The primary data were, then, examined by using path analysis to reveal the correlations and predicted paths among the constructed variables, which included vocabulary, speaking, and writing. The examination was conducted separately to each group level of students, which consisted of beginner and intermediate level students. Thus, the results of the examination could also be analyzed from comparative perspective on both levels of students.

This study involved beginner and intermediate level students, as explained below.

\section{Beginner level students}

Students in this level are those whose scores were in the range of $40-55$ in the university placement test in 2017. In this paper, these students are 
also referred as basic users of English at A1 level, based on the Common European Framework of Reference for Languages (CEFR). In total, there were 361 students in this level, but this study only used the data of 10 classes of English in Cultural Diversity or 215 beginner level students. The students majored in Electrical Engineering, Chinese Language, Tourism and Hotel, Management, Accounting, and Health. Since gender was not the variable of interest, it was not specified.

\section{Intermediate level students}

These students obtained scores in the range of 56 - 69 in the university placement test in 2017, equivalent to B1/B2 level in CEFR. Seven classes

of intermediate level students were chosen as the sample for this study, which involved 195 students. They majored in Electrical Engineering, Medical Technology, and Nursing. Gender was also intentionally not specified.

Following the purpose of the study explained earlier, the instruments and materials used for data collection involve vocabulary, speaking, and writing.

To set up vocabulary acquisition through self-regulated learning, ten vocabulary sets were created and attached to the course book. One vocabulary set contained 50 words along with the information of part of speech, definition, and example in sentence. In the implementation, students had to learn one vocabulary set outside classroom schedule for each week. Then, a vocabulary test was given to the students in class. For instance, students learned vocabulary set 1 after class in week 1, then they would be tested in class in week 2 . The vocabulary learning, and assessment were done in such process until week 11 where students would have the last vocabulary test, i.e. vocabulary test 10 . In this system, students had to self-regulate their own learning to acquire the 50 words in the assigned vocabulary set for each week. They were free to use any available learning resources and teachers were reachable through Facebook.

Following the vocabulary sets, ten vocabulary tests were created to measure students' vocabulary acquisition for each vocabulary set or each week. The vocabulary tests consisted of 15 questions encompassing synonym, antonym, sentence completion, and definition. The questions were about the words listed in the assigned vocabulary sets, so students should have known the words if the studied the vocabulary set prior to the vocabulary tests. In addition, some pictures were added to some questions in each vocabulary test. After that, the vocabulary tests were delivered by using Socrative.com, a website or mobile app that allows a real-time quiz by using smartphones. The tests were given in the first 15 minutes of each class and teacher could access the result report after class. The average of students' scores from these ten vocabulary tests were used as the primary data in this study. It was considered 
as the vocabulary acquisition through self-regulated learning variable.

Table 1. One of the vocabulary sets

\begin{tabular}{|c|c|c|c|c|}
\hline No. & Word & $\begin{array}{l}\text { Part of } \\
\text { Speech }\end{array}$ & Definition & Example \\
\hline 1. & Air hostess & Noun & $\begin{array}{l}\text { An air hostess is a woman } \\
\text { who serves passengers on } \\
\text { an aircraft. }\end{array}$ & $\begin{array}{l}\text { Her salary as an air hostess } \\
\text { was enough to send all her } \\
\text { children to college. }\end{array}$ \\
\hline 2. & Airline & Noun & $\begin{array}{l}\text { The airline or carrier you } \\
\text { fly with is the name of the } \\
\text { company that owns the } \\
\text { airplane e.g. Singapore } \\
\text { Airlines, British Airways. }\end{array}$ & $\begin{array}{l}\text { Nok Air and Thai Lion are } \\
\text { the only airlines that serve } \\
\text { the Bangkok-Nakhon Si } \\
\text { Thammarat route. }\end{array}$ \\
\hline 3. & Arrivals & Noun & $\begin{array}{l}\text { When your plane arrives } \\
\text { at the airport, your family } \\
\text { and friends will meet you } \\
\text { at arrivals. }\end{array}$ & $\begin{array}{l}\text { We'll be waiting for you at } \\
\text { the arrivals. }\end{array}$ \\
\hline$\ldots \ldots$ & n.w. & n.w. & 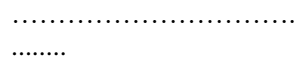 & 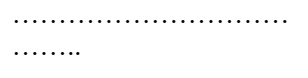 \\
\hline 50. & Board & Verb & $\begin{array}{l}\text { To board (a plane) means } \\
\text { to go onto it. }\end{array}$ & $\begin{array}{l}\text { We will be boarding in half } \\
\text { an hour. }\end{array}$ \\
\hline
\end{tabular}

Table 2. Example of the questions in the vocabulary tests

\begin{tabular}{ll}
\hline No. & \multicolumn{1}{c}{ Questions } \\
\hline 1. & "Mardi Gras is a carnival held on Shrove Tuesday." What is the part of speech of the word \\
& "CARNIVAL"in the sentence?
\end{tabular}

A. Noun

B. Verb

C. Adverb

D. Adjective

2. What time does the concert ...?
A. Custom
B. begin
C. attend
D. crowd

3. In 1836, the Director began to ...... a grand conservatory $300 \mathrm{ft}$.
A. play
B. erect
C. watch
D. cry

As the variable for students' development in speaking, students' scores on two speaking tests were utilized in this study, which consisted of theme-based role play and individual interview exams, as elaborated below.

Theme-based role play

In the course design, students were required to perform four theme-based role-plays in a group of $4-5$ in class. The themes of the role play reflected the topics of four units in the course textbook, which involved Airport, Restaurant, Studying Abroad, and Festivals, Arts, and Crafts. The instruction of the 
role play was attached to the course textbook. Students' role-play performances were assessed by using a rubric that included five criteria: vocabulary use, fluency, accuracy, interaction, and creativity, preparedness, and prompts. The scores ranged from 2.5 to 10 .

\section{Individual interview exams}

At the end of the term, each student was given an individual interview exam. After experiencing vocabulary acquisition through self-regulated learning and speaking practices in the four theme-based role-plays, students' speaking development was expected to be noticeable in this interview exam. The exam was designed to reveal students' abilities in explaining personal information, pronouncing word, phrases, and sentences, and communicating and expressing ideas relating to the course materials. An assessment rubric was also prepared for this exam, which involved five criteria: content, vocal expression, presentation, fluency and accuracy, and listening skill. The scores also ranged from 2.5 to 10 .

The detailed implementation of these two speaking tests can be seen in the class schedule below.

Table 3. Class schedule

\begin{tabular}{cl}
\hline Week & Material \\
\hline 2 & Unit 1: Airport \\
\hline 3 & Role-play performance and Writing Practice \\
\hline 4 & Unit 2: Restaurant \\
\hline 5 & Role-play performance and Writing Practice \\
\hline 6 & Unit 3: Living Abroad \\
\hline 7 & Role-play performance and Writing Practice \\
\hline 9 & Unit 4: Festivals, Arts, and Crafts \\
\hline 10 & Role-play performance and Writing Practice \\
\hline 11 & Review of Lessons \\
\hline 12 & Final Speaking Test \\
\hline
\end{tabular}

At the end the variable of writing development involved two writing tests, namely writing practice and final writing test, elaborated below.

\section{Writing practice}

After studying each unit in the course textbook (table 3), students were required to write a short reflective essay on Writeabout.com. The essays were read and given feedback by teachers through Writeabout.com. Students revised their essays at least three times until the final assessment took place in week 9.

\section{Final writing test}

Students were given a final writing test in week 12 (table 3). The test required students to choose one prompt to respond to and write a short passage of 100-150 words to elaborate their response. The prompts were related to the 
course materials.

Both tests were assessed by using the same rubric, which involved five criteria: task achievement, grammar, vocabulary, logics, and mechanics (spelling, punctuation, and capitalization). The scores ranged from 2.5 to 10.

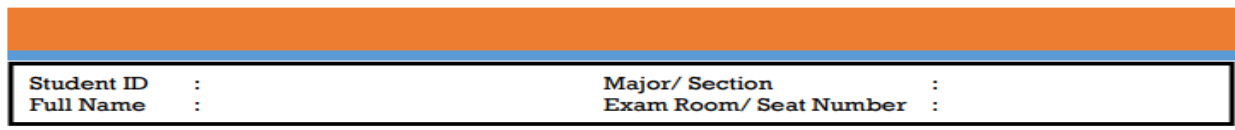

PART 5: WRITING

Instructions: Choose and circle ONLY ONE (1) prompt to respond to and write a short passage of 100150 words to elaborate your response.

Prompt 1: Studying abroad has received a lot of attention recently. Do you think students should go abroad, at least once, during their undergraduate studies? Give reasons or examples to support your opinion.

Prompt 2: Nowadays, people not only celebrate local festivals, but also foreign festivals. Would you agree that foreign festivals bring no harm to local cultures?

Picture 1. The appearance of the final writing test question

Basically, this study used vocabulary acquisition through self-regulate learning as the independent variable. The data were collected through 10 vocabulary tests given to students from week 2 to 11 . Then, the dependent variable involved speaking in theme-based role play, final speaking test, writing practice, and final writing test. The data for speaking in theme-based role play were collected through role play performances in week $3,5,7$, and 9 , while the final speaking test was conducted in 11 and 12. Like role play, the data for writing practice were also collected in week $3,5,7$, and 9 through a reflective essay assignment. The final writing test took place in week 12 . These steps in data collection followed the course schedule, shown in table 3. In the data analysis stage, students' scores in vocabulary tests, speaking-role play, final speaking test, writing practice, and final writing test were cleaned up for both beginner and intermediate students. After that, bivariate correlation analysis was run by using SPSS and then, followed by path analysis by a means of MPlus. The purpose of the path analysis was to disclose the significant paths between vocabulary acquisition through self-regulated learning to speakingrole play, final speaking test, writing practice, and final writing test. The findings were presented as follows. 


\section{Findings and discussion}

The Prior to the path analysis, bivariate correlation analysis was run between vocabulary acquisition and the variables of speaking and writing for both levels: beginner and intermediate level students. For beginner level students, the results disclose that vocabulary acquisition was significantly correlated with speaking-role play ( $r=.33, p<.001)$, writing practice $(r=.24, p<.001)$, final writing test $(r=.20, p=.004)$, but not with final speaking test $(r=.10, p=$ .133). Meanwhile, speaking-role play was significantly correlated with final speaking test ( $r=-.14, p=.044$ ) and writing practice was significantly correlated with final writing test $(r=.35, p<.001)$.

Then, the results of the correlations among the variables in intermediate level students reveal that vocabulary acquisition was significantly correlated with the variables of speaking and writing, including speaking-role play $(r=.32$, $p<.001)$, final speaking test $(r=.27, p<.001)$, writing practice $(r=.20, p=$ $.004)$, and final writing test $(r=.27, p<.001)$. Besides, speaking-role play was significantly correlated with final speaking test $(r=.28, p<.001)$ and writing practice was with final writing test $(r=46, p<.001)$. Table 4 and 5 below provide the detailed numbers. These significant relationships among variables permit path analysis to be conducted.

Table 4. The Results of Bivariate Correlations - Beginner

\begin{tabular}{lcccc}
\hline $\mathbf{1}-$ Vocabulary Acquisition & $\mathbf{2}$ & $\mathbf{3}$ & $\mathbf{4}$ & $\mathbf{5}$ \\
\hline $\mathbf{2}-$ Speaking (Role-Play) & $.334^{* *}$ & .103 & $.236^{* *}$ & $.196^{* *}$ \\
\hline 3-Final Speaking Test & & $-.138^{*}$ & .074 & -.113 \\
\hline 4-Writing Practice & & $.170^{*}$ & $.591^{* *}$ \\
\hline $\mathbf{5}-$ Final Writing & & & $.353^{* *}$ \\
\hline Notes. $* \mathrm{p}<.05, * * \mathrm{p}<.01, * * * \mathrm{p}<.001$, two tailed tests. & & & 1 \\
\hline
\end{tabular}

Table 5. The Results of Bivariate Correlations - Intermediate

\begin{tabular}{lcccc}
\hline & $\mathbf{2}$ & $\mathbf{3}$ & $\mathbf{4}$ & $\mathbf{5}$ \\
\hline $\mathbf{1}$ - Vocabulary Acquisition & $.317^{* *}$ & $.265^{* *}$ & $.204^{* *}$ & $.273^{* *}$ \\
\hline $\mathbf{2}$ - Speaking (Role-Play) & & $.284^{* *}$ & $.181^{*}$ & $.273^{* *}$ \\
\hline $\mathbf{3}$ - Final Speaking Test & & $.316^{* *}$ & $.466^{* *}$ \\
\hline $\mathbf{4}$ - Writing Practice & & $.464^{* *}$ \\
\hline $\mathbf{5}$ - Final Writing & & & 1 \\
\hline Notes. ${ }^{*} \mathrm{p}<.05, * * \mathrm{p}<.01, * * * \mathrm{p}<.001$, two tailed tests. & &
\end{tabular}

Next, the data of beginner and intermediate level students were examined by using path analysis. Since the paths of interests were clear and uncomplicated, the path analysis was only conducted for one time for each level of the students and this condition was considered enough to disclose the answers for the research question. The model fit was assessed by employing three indexes, consisting of comprised of root mean square error of approximation (RMSEA), Tucker-Lewis index (TLI), and comparative fit index (CFI). The 
values for a good fit are RMSEA (.06), TLI ( $\geq .95)$, and CFI ( $\geq .95$ ) (Jackson, Gillaspy Jr, \& Purc-Stephenson, 2009). RMSEA has been used by most empirical studies, where values less than .5 are considered good and lower than .8 are acceptable (McDonald \& Ho, 2002). The details for each level student are provided below.

\section{Beginner level students}

The values of RMSEA (.05) and TLI (.96) showed a good fit, but acceptable for the value of CFI for the examined model. The chi-square of model fit was 8.984 $(d f=2, p=0.01)$ and $173.346(d f=10, p<.001)$ for the baseline model. The analysis results display that significant paths were found from vocabulary acquisition through self-regulated learning to students' improvement in speaking-role play $(\beta=.177, S E=.034, p<.001)$, writing practice $(\beta=.135, S E=$ $.038, p<.001)$, and final writing test $(\beta=.145, S E=.049, p=.003)$, but the path to final speaking test was not significant. However, the $\mathrm{R}^{2}$ values in the significant paths indicate that the independent variable did not explain much of the variability in the dependent variables: Speaking-role play $\left(R^{2}=.11\right)$, writing practice $\left(R^{2}=.06\right)$, and final writing test $\left(R^{2}=.04\right)$. These results suggest that vocabulary acquisition was not the only contributor to students' improvement in speaking and writing, and obviously not the major one either. Figure 1 below illustrates the paths with standardized regression coefficients.

Figure 1. The path analysis results - beginner students

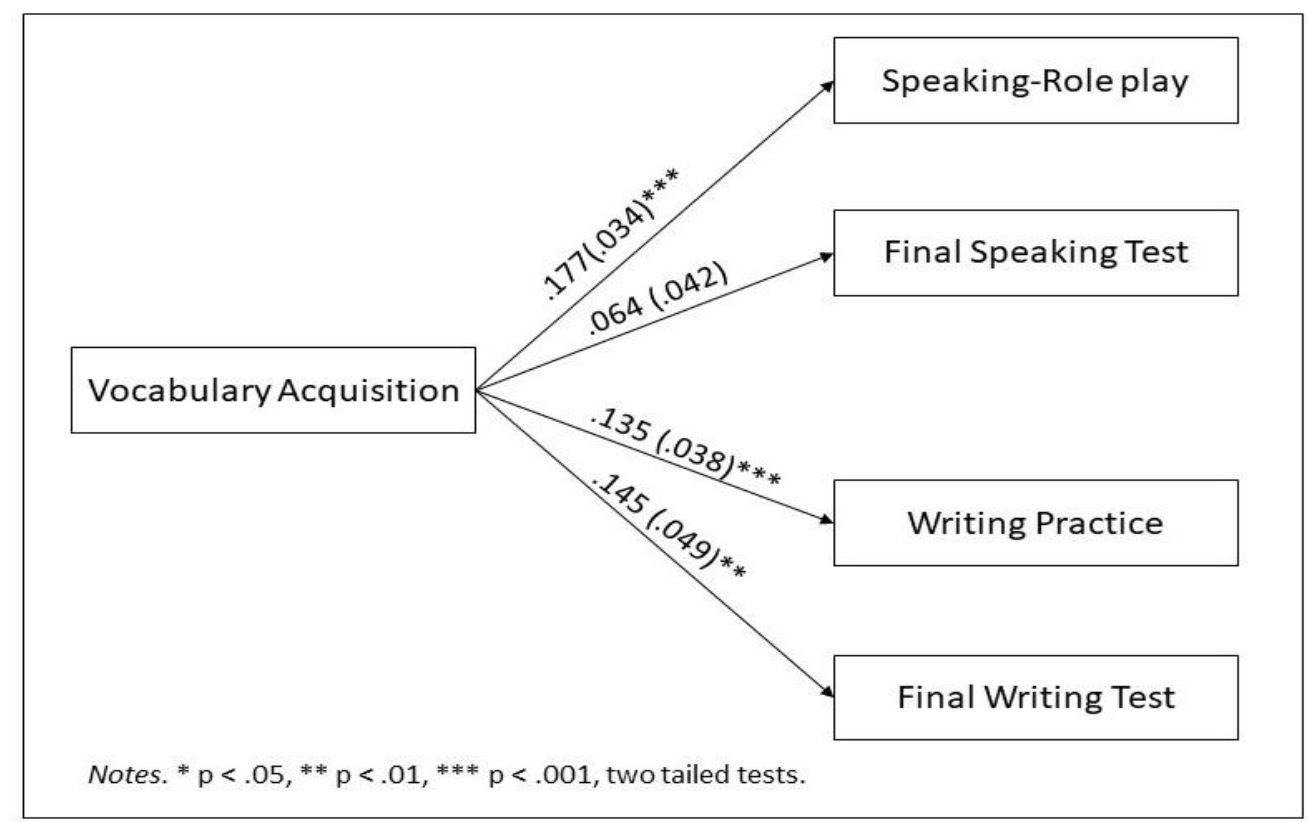




\section{Intermediate Level Students}

The values obtained from the path analysis on intermediate level students indicate no significant difference between the actual data and the expected data with the chi-square value at $0, p=.001$. The model was considered good as reflected in the values of the indexes: RMSEA (.001), TLI (1), and CFI (1). Different from the results of beginner level students, significant paths were obtained from vocabulary acquisition through self-regulated learning to students' improvement in speaking-role play $(\beta=.269, S E=.058, p=.001)$, final speaking test $(\beta=.231, S E=.060, p=.001)$, writing practice $(\beta=.194, S E=$ $.067, p=.004)$, and final writing test $(\beta=.256, S E=.065, p=.001)$. Nonetheless, based on the $\mathrm{R}^{2}$ values, these significant paths did not explain much of the variability in the dependent variables: speaking-role play $\left(R^{2}=.10\right)$, final speaking test $\left(R^{2}=.07\right)$, writing practice $\left(R^{2}=.04\right)$, and final writing test $\left(R^{2}=.08\right)$. These findings were consistent with the findings from beginner level students, implying that vocabulary acquisition through self-regulate learning was not the only contributor to students' improvement in speaking and writing. The following figure 2 displays the detailed paths.

Figure 2. The path analysis results - intermediate students

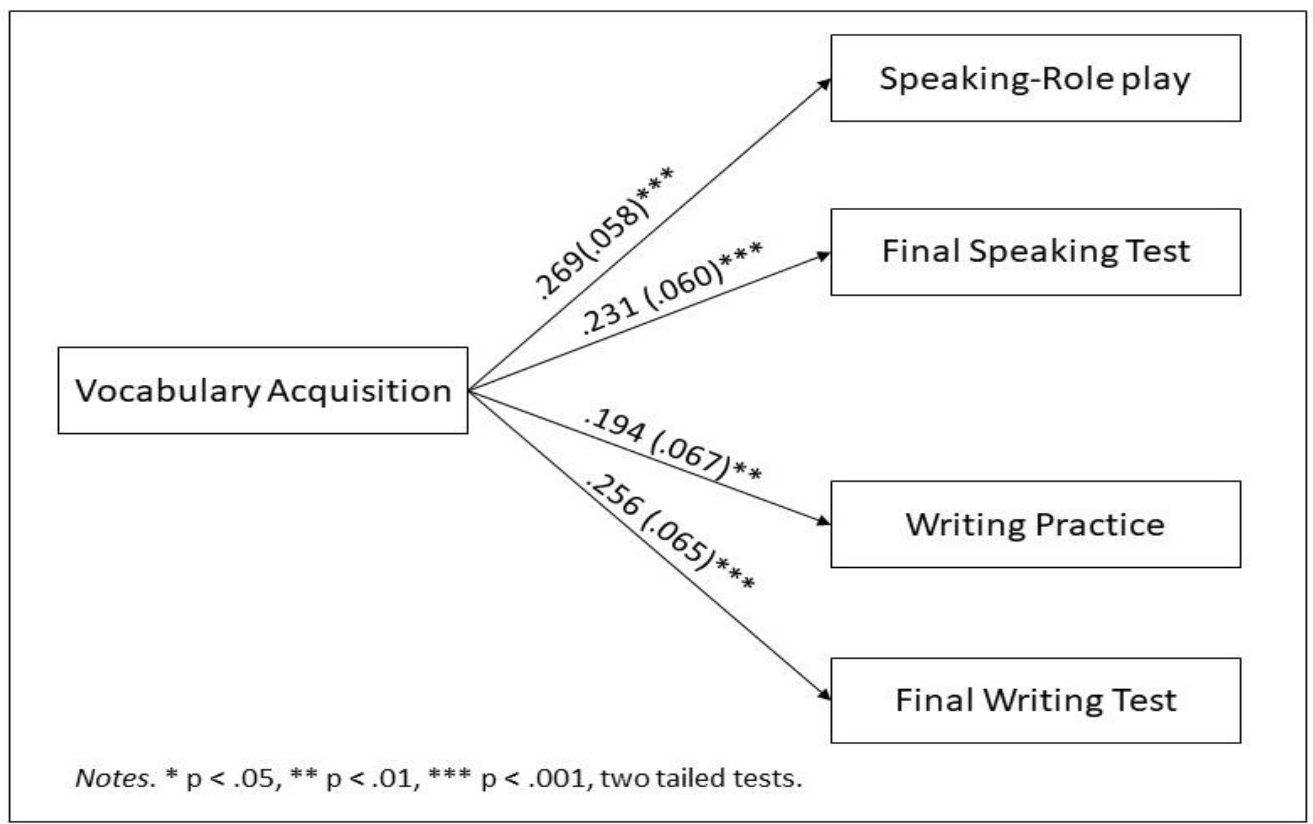

One of the insights obtained through the path analysis in this study is that students' vocabulary acquisition through self-regulated learning significantly influenced their development in writing. Both beginner and intermediate students displayed the significant paths, depicted in figure 1 and 2. This finding sustains the argument that vocabulary acquisition plays a crucial role in writing development. Inadequate knowledge of the target language 
vocabulary can lead to inferior writing quality (Shi \& Qian, 2012). The finding concurs with Viera (2017) who studied the influence of vocabulary knowledge on written production. By employing an experimental research design, the study discovered that a group of students receiving vocabulary activities performed better in written production than those who did not receive such intervention. However, it must be admitted that despite the essential role of vocabulary in the acquisition of the four English skills, the number of research exploring the link from vocabulary to writing development is still limited. The present study, hence, encourages the future research in this area, so more empirical evidence can be found to sustain the mentioned argument earlier.

Another insight from the results of this study is that vocabulary acquisition through self-regulated learning was a predictor of students' development in speaking for intermediate students, but not for beginner students. This also follows the findings of the previous studies. For instance, Koizumi (2005) examined the relationship between vocabulary and speaking ability of Japanese EFL learners at beginner level. The finding suggests the substantial effects of vocabulary knowledge on learners' speaking ability. In another study, it was found that learners with higher level of proficiency also exhibited higher vocabulary knowledge, which accounted for their high speaking ability (Koizumi \& In'nami, 2013). The inconsistent significance of the paths from vocabulary acquisition to speaking-role play and final speaking in this study implies that beginner students may show some improvement in speaking due to acquiring more vocabulary, but the level of improvement is limited and may depend of the type of the assigned speaking task. In this study, for instance, beginner students were faced with one on one conversation with teacher, which would directly attest their speaking ability. In such circumstances, aside from their low level of proficiency, beginner students had to cope with other difficulties in speaking too, such as selfconfidence, fluency and accuracy, listening comprehension, and so forth, which might have hindered them from good performances.

Overall, the findings of this study contribute to the research on vocabulary acquisition in the context of speaking and writing development. Acquiring wider and deeper vocabulary knowledge is essential for students' development in speaking and writing (Belisle, 1997; Jordan, 1997; Milton, 2013; Sydow, 2015), yet the effects may vary across learners, depending on their levels of proficiency in the target language (Iwashita, 2005). Therefore, the present study would encourage vocabulary acquisition through selfregulated learning, but with more explicit instructions that can help low level students' focus during the learning process. Directing students' vocabulary learning to exam purpose may work better in enhancing students' use of the 
newly taught vocabulary (Dobbs \& Kearns, 2016).

\section{Conclusions}

The results of the analysis confirm that vocabulary acquisition through selfregulated learning can influence students' development in speaking and writing, but the influence level may vary across learners with different levels of proficiency. This study establishes a sound foundation for further exploration and discussion around the contribution of vocabulary acquisition in speaking and writing development. For future studies, it is recommended to consider other aspects that may hinder learners from improving their speaking and writing skills.

\section{References}

[1] Belisle, T. A. (1997). Developing vocabulary knowledge in the immersion classroom.

[2] Bjork, R. A., Dunlosky, J., \& Kornell, N. (2013). Self-regulated learning: Beliefs, techniques, and illusions. Annual review of psychology, 64, 417444.

[3] Boekaerts, M. (1997). Self-regulated learning: A new concept embraced by researchers, policy makers, educators, teachers, and students. Learning and Instruction, 7(2), 161-186. doi.org/10.1016/s0959$\underline{4752(96) 00015-1}$

[4] Choi, Y., Zhang, D., Lin, C. H., \& Zhang, Y. (2018). Self-regulated learning of vocabulary in English as a Foreign Language. The Asian EFL Journal Quarterly, 20(1), 52-82.

[5] De la Fuente, M. J. (2006). Classroom L2 vocabulary acquisition: Investigating the role of pedagogical tasks and form-focused instruction. Language Teaching Research, 10(3), 263-295. doi.org/10.1191/1362168806/r1960a

[6] DiFrancesca, D., Nietfeld, J. L., \& Cao, L. (2016). A comparison of high and low achieving students on self-regulated learning variables. Learning and Individual Differences, 45, 228-236._doi.org/10.1016/j.lindif.2015.11.010

[7] Dobbs, C. L., \& Kearns, D. (2016). Using new vocabulary in writing: Exploring how word and learner characteristics relate to the likelihood that writers use newly taught vocabulary. Reading and Writing, 29(9), 18171843.

[8] Dörnyei, Z. (1990). Conceptualizing motivation in foreign-language learning. Language learning, 40(1), 45-78._doi.org/10.1111/j.14671770.1990.tb00954.x

[9] Dörrenbächer, L., \& Perels, F. (2016). Self-regulated learning profiles in college students: Their relationship to achievement, personality, and the effectiveness of an intervention to foster self-regulated learning. Learning and Individual Differences, 51, 229-241. 
doi.org/10.1016/j.lindif.2016.09.015

[10] Duckworth, K., Akerman, R., MacGregor, A., Salter, E., \& Vorhaus, J. (2009). Self-regulated learning: a literature review. [Wider Benefits of Learning Research Report No. 33].

[11] Farvardin, M. T., \& Valipouri, L. (2017). Probing the relationship between vocabulary knowledge and listening comprehension of Iranian lower-intermediate EFL learners. International Journal of Applied Linguistics and English Literature, 6(5),

273-278. doi.org/10.7575/aiac.ijalel.v.6n.5p.273

[12] Fukuda, A. (2018). Examining the relationship between self-regulated learning and EFL learners' proficiency. Intercultural Communication Review, 16, 17-31.

[13] Hamedani, S. H. H. (2013). The relationship between self-efficacy and self-regulation in vocabulary acquisition of Iranian EFL learners. Journal of Academic and Applied Studies, 3(1), 20-31.

[14] Harkio, N., \& Pietilä, P. (2016). The role of vocabulary breadth and depth in reading comprehension: A quantitative study of finish EFL learners. Journal of Language Teaching and Research, 7(6), 1079-1088. doi.org/10.17507/iltr.0706.03

[15] Iwashita, N. (2005). An investigation of lexical profiles in performance on EAP speaking tasks. Spaan Fellow Working Papers in Second or Foreign Language Assessment Volume, 3,101.

[16] Jackson, D. L., Gillaspy Jr, J. A., \& Purc-Stephenson, R. (2009). Reporting practices in confirmatory factor analysis: an overview and some recommendations. Psychological

Methods, 14(1),

6. doi.org/10.1037/a0014694

[17] Jordan, R. R. (1997). English for academic purposes: A guide and resource book for teachers. Cambridge: Cambridge University Press.

[18] Karakoç, D., \& Köse, G. D. (2017). The impact of vocabulary knowledge on reading, writing and proficiency scores of EFL learners. Journal of Language and Linguistic Studies, 13(1), 352-378.

[19] Khan, R. M. I., Radzuan, N. R. M., Shahbaz, M., Ibrahim, A. H., \& Mustafa, G. (2018). The Role of vocabulary knowledge in speaking development of Saudi EFL Learners.doi.org/10.24093/awej/vol9no1.28

[20] Khodarahmi, E., \& Zarrinabadi, N. (2016). Self-regulation and academic optimism in a sample of Iranian language learners: Variations across achievement group and gender. Current Psychology, 35(4),700-710. doi.org/10.1007/s12144-015-9340-z

[21] Kim, S. Y., \& Ryoo, Y. S. (2009). Korean college students' vocabulary profiles as predictors of English reading and writing proficiency. Multimedia Assisted Language Learning, 12(3), 93-115.

[22] Koizumi, R. (2005). Predicting speaking ability from vocabulary knowledge. JLTA Journal, 7, 1-20. 
[23] Koizumi, R., \& In'nami, Y. (2013). Vocabulary knowledge and speaking proficiency among second language learners from novice to intermediate levels. Journal of Language Teaching \& Research, 4(5). doi.org/10.4304/jltr.4.5.900-913

[24] Kormos, J., \& Csizer, K. (2014). The interaction of motivation, self-regulatory strategies, and autonomous learning behavior in different learner groups. Tesol Quarterly, 48(2), 275-299.doi.org/10.1002/tesq.129

[25] Lee, S. H. (2003). ESL learners' vocabulary use in writing and the effects of explicit vocabulary instruction. System, 31(4), 537-561. doi.org/10.1016/j.system.2003.02.004

[26] Lindner, R. W., \& Harris, B. (1992). Self-regulated learning and academic achievement in college students.

[27] McDonald, R. P., \& Ho, M. H. R. (2002). Principles and practice in reporting structural equation analyses. Psychological Methods, 7(1), 64. doi.org/10.1037//1082-989x.7.1.64

[28] Milton, J. (2013). Measuring the contribution of vocabulary knowledge to proficiency in the four skills. C. Bardel, C. Lindqvist, \& B. Laufer (Eds.). 2, 57-78.

[29] Mizumoto, A. (2013a). Enhancing self-efficacy in vocabulary learning: A self-regulated learning approach. Vocabulary Learning and Instruction, 2(1), 15-24.

[30] Mizumoto, A. (2013b). Effects of self-regulated vocabulary learning process on self-efficacy. Innovation in Language Learning and Teaching, 7(3), 253-265.doi.org/10.1080/17501229.2013.836206

[31] Mizumoto, A., \& Takeuchi, O. (2011). Adaptation and validation of selfregulating capacity in vocabulary learning scale. Applied Linguistics, 33(1), 83-91.doi.org/10.1093/applin/amr044

[32] Mizumoto, A., \& Takeuchi, O. (2009). Examining the effectiveness of explicit instruction of vocabulary learning strategies with Japanese EFL university students. Language Teaching Research, 13(4), 425-449. doi.org/10.1177/1362168809341511

[33] Nassaji, H. (2006). The relationship between depth of vocabulary knowledge and L2 learners' lexical inferencing strategy use and success. The Modern Language Journal, 90(3), 387-401. doi.org/10.1111/j.1540-4781.2006.00431.x

[34] Olinghouse, N. G., \& Wilson, J. (2013). The relationship between vocabulary and writing quality in three genres. Reading and Writing, 26(1), 4565. doi.org/10.1007/s11145-012-9392-5

[35] Ping, A. M., Baranovich, D. L., Manueli, M. K., \& Siraj, S. (2015). Promoting self-regulation in vocabulary learning among Chinese EFL learners: A needs analysis. The Asia-Pacific Education Researcher, 24(1), 137-146. doi.org/10.1007/s40299-013-0166-x

[36] Schmitt, N. (2008). Instructed second language vocabulary learning. Language Teaching Research, 12(3), 329-363. doi.org/10.1177/1362168808089921 
[37] Seffar, S. (2011). The Effect of Vocabulary Knowledge on EFL Oral Competence. IOSR Journal of Research \& Method in Education, 5(6), 08-13.

[38] Shi, L., \& Qian, D. (2012). How does vocabulary knowledge affect Chinese EFL learners' writing quality in web-based settings? Evaluating the relationships among three dimensions of vocabulary knowledge and writing quality. Chinese Journal of Applied Linguistics, (1), 117-127. doi.org/10.1515/cjal-2012-0009

[39] Siyanova-Chanturia, A., \& Webb, S. (2016). Teaching vocabulary in the EFL context, In English Language Teaching Today(pp. 227-239). Springer, Cham.doi.org/10.1007/978-3-319-38834-2 16

[40] Sökmen, A. J. (1997). Current trends in teaching second language vocabulary. Readings in Methodology, 152.

[41] Tseng, W. T., Dörnyei, Z., \& Schmitt, N. (2006). A new approach to assessing strategic learning: The case of self-regulation in vocabulary acquisition. Applied Linguistics, 27(1), 78-102._doi.org/10.1093/applin/ami046

[42] Tseng, W. T., \& Schmitt, N. (2008). Toward a model of motivated vocabulary learning: A structural equation modeling approach. Language Learning, 58(2), 357-400. doi.org/10.1111/j.1467-9922.2008.00444.x

[43] Viera, R. T. (2017). Vocabulary knowledge in the production of written texts: a case study on EFL language learners. Revista TecnológicaESPOL, 30(3).

[44] Sydow, A. V. (2015). Vocabulary acquisition. Possibilities within the taskbased framework.

[45] Zhai, L. (2016). A study on Chinese EFL learners' vocabulary usage in writing. Journal of Language Teaching and Research, 7(4), 752-759. doi.org/10.17507/jltr.0704.16

[46] Zhang, Y. (2011). The use of vocabulary learning strategies by good and poor language learners: A case study of Chinese non-English major sophomores.

[47] Zhang, Y., Lin, C. H., Zhang, D., \& Choi, Y. (2017). Motivation, strategy, and English as a foreign language vocabulary learning: A structural equation modelling study. British Journal of Educational Psychology, 87(1), 57-74. doi.org/10.1111/bjep.12135

[48]Zimmerman, B. J. (2008). Investigating self-regulation and motivation: Historical background, methodological developments, and future prospects. American Educational Research Journal, 45(1), 166-183. doi.org/10.3102/0002831207312909

[49]Zimmerman, B. J. (2002). Becoming a self-regulated learner: An overview. Theory into practice, 41(2), 64-70. doi.org/10.1207/s15430421tip4102 2

[50] Zimmerman, B. J. (1990). Self-regulated learning and academic achievement: An overview. Educational Psychologist, 25(1), 3-17. doi.org/10.1207/s15326985ep2501 2 